\title{
TEOLOGI NATURALISME DAN IMPLIKASINYA TERHADAP PARADIGMA PERADABAN MANUSIA KONTEMPORER
}

\author{
Himyari Yusuf \\ IAIN Raden Intan Lampung \\ himyar_yusuf@yahoo.com
}

\begin{abstract}
Abstrak
Artikel inimembahastentangteologinaturalismeyang telahmengantarkan peradaban modern yang positivisik. Persoalan idealisme metafisika atau super-naturalis mulai terkikis atau cenderung tidak lagi mendapatkan tempat dalam pemikiran barat modern karena telah dialihkan pada hal-hal yang konkret atau positifistik. Teologi naturalisme merupakan paham yang korelatif dengan filsafat alam. Paham theologi naturalisme semata-mata bersandarkan pada keberadaan alam dan kemampuan akal manusia. Teologi naturalisme memandang bahwa alam kesemestaan ini berjalan dengan sendirinya dalam arti tanpa intervensi Tuhan. Tuhan diyakini sebagai pencipta alam, namun setelah alam diciptakan Tuhan pergi keluar alam. Selain itu teologi naturalisme juga menolak semua yang bersifat metafisik dan spiritual yang ada dalam agama-agama. Agama dianggap benar manakala kebenarannya bersifat alamiah. Secara faktual teologi naturalisme telah berimplikasi terhadap sebahagian besar peradaban umat manusia kontemporer. Tampilan perilaku kekerasan, kebebasan seks, korupsi dan lain sebagainya, secara filosofis adalah representasi dari teologi yang tanpa Tuhan, tanpa spiritual-metafisik dan agama.
\end{abstract}

\section{Abstract}

NATURALISMTHEOLOGYAND ITS IMPLICATIONSTOTHECONTEMPORARY HUMAN CIVILIZATION PARADIGMS. This article discusses the theology of naturalism which has led modern civilization to become more positivistic. Metaphysics idealism and super-natural issue have been eroded and no longer have a place in modern western thought as they have been transferred to concrete things or positivistics. Theology of naturalism, which is closely related to natural philosophy, relies solely on the existence of nature and 
the ability of human reasoning. Theology of naturalism views that nature runs its universality without the intervention of God. God is believed to be the creator of the universe; but after the nature is created, God goes out of nature. In addition, theology of naturalism also rejects all metaphysics and spiritual existing in religions. Religion is considered true if the truth is natural. Factually, theology of naturalism has implications to the greater part of contemporary human civilization. The increase in violent behavior, sexual freedom, corruption and so forth, philosophically, is a representation of philosophy without God, without metaphysic-spiritual and religion.

Kata Kunci : Teologi Naturalisme; Spiritual-metafisik; Agama; Peradaban Kontemporer.

\section{A. Pendahuluan}

Pengkajian tentang kepercayaan kepada Tuhan dan agama merupakan suatu persoalan yang sangat aktual pada era belakangan ini. Hal ini dapat dibuktikan bahwa di mana dan kapan saja ada kehidupan manusia, pasti akan ditemukan permasalahan tentang kepercayaan kepada Tuhan dan agama. Berdasarkan fakta semacam itulah, maka dapat dipastikan permasalahan kepercayaan kepada Tuhan dan agama tidak terlepas dari kehidupan segenap umat manusia. Kenyataan tersebut secara falsafati bukanlah sesuatu yang tidak rasional, karena secara kodrati kepercayaan kepada Tuhan dan agama merupakan bawaan hidup manusia semenjak dilahirkan, oleh karena itu pengkajian tentang kepercayaan kepada Tuhan dan agama dapat dan akan berlangsung sepanjang manusia masih mengada dalam kesemestaan.

Kepercayaan akan Tuhan dan agama pada era kontemporer menjadi semakin kompleks dan rumit. Kompleksitas masalah tersebut secara kausalitas dapat dikatakan sebagai akibat dari perkembangan ilmu pengetahuan dan teknologi yang demikian cepat dan spektakuler. Pemahaman atas kepercayaan kepada Tuhan dan agama pada era ini dapat dikatakan telah terbagi ke dalam dua golongan. Pertama, golongan yang memahami adanya Tuhan dan agama bersandarkan pada kemampuan dan keputusan akal serta menjadikan alam sebagai dasar paling utama. Kedua, adalah golongan yang memahami adanya Tuhan dan agama dengan bersandarkan pada wahyu dan berbagai penjelasan rasul-Nya sebagai landasan utama. Golongan pertama yang kemudian disebut sebagai "Teologi Naturalisme" dan golongan kedua kemudian disebut 
sebagai "Teologi Wahyu". Kedua model teologi tersebut secara reflektif tentunya memiliki persamaan, walaupun terdapat juga perbedaanperbedaan yang sangat mendasar dan signifikan, terutama pada dasar epistemologis dari masing-masing model teologi tersebut. Berbagai perbedaan itulah yang menimbulkan benturan-benturan, bahkan bertolak belakang atau kontradiktoris yang sangat ekstrim.

Berdasarkan fakta sejarah dunia filsafat, diketahui bahwa teologi naturalisme modern menampakkan paham-pahamnya yang radikal semenjak abad ke 16, 17 dan 18, yang diawali oleh gerakan humanisme di Italia pada abad ke 14 kemudian gerakan renaissance dan aufklarung yang terjadi pada masa berikutnya. Gerakan-gerakan tersebut pada awalnya bertujuan untuk meningkatkan harmonisasi dari sifat dan kecakapan alamiah manusia. ${ }^{1}$ Tema atau slogan yang paling mengemuka pada masa itu adalah bahwa "hal-hal yang alamiah pada diri manusia sendiri telah memiliki nilai cukup untuk dijadikan sebagai landasan dan sasaran bagi pengenalan dan penguasaan hidup manusia”.

Semenjak kurun waktu tersebut di atas persoalan idealisme metafisika atau super-naturalis mulai terkikis atau cenderung tidak lagi mendapatkan tempat dalam pemikiran Barat modern, permasalahan metafisika dialihkan pada hal-hal yang konkret atau positifistik. Kenyataan itu dapat dibuktikan dalam ranah teoriteori ilmiah, bahwa semua persoalan kehidupan manusia harus berkategori positifistik ilmiah. Kategori ilmiah harus objektif dan dapat dibuktikan secara positifistik, sehingga yang dianggap sebagai suatu kebenaran ilmiah adalah yang sesuai dengan fakta yang nyata, kemudian sebaliknya semua hal yang bersifat metafisik, abstrak dan sebagainya dianggap hanya suatu kebenaran yang bersifat ilusi, khayalan dan sia-sia bagi kehidupan manusia.

\section{B. Pengertian dan Perkembangan Teologi Naturalisme}

Secara umum, teologi naturalisme juga sering dikatakan filsafat ketuhanan yang berpangkal semata-mata pada kejadian alam dan menggunakan kekuatan akal murni. Dalam hal ini Elias A. Elias mendefinisikan teologi naturalisme sebagai penselarasan

${ }^{1}$ Harun Hadiwiyono, Sari Sejarah Filsafat Barat 2, (Yogyakarta: Kanisius, 1991), h. 11. 
masalah-masalah agama (isi kitab) dengan pengetahuan alam. ${ }^{2}$ Sementara Hasbullah Bakry mengatakan teologi naturalisme juga disebut teodecea atau ilmu yang menyelidiki bagaimana keadilan Tuhan dalam keteraturan dan pemeliharaan alam ${ }^{3}$. Relevan dengan kedua pengertian tersebut Lewis Muford menjelaskan bahwa teologi naturalisme adalah pengetahuan tentang Tuhan yang dijangkau dari mempelajari alam lahiriyah semata ${ }^{4}$.

Adapun mengenai asal-usul tumbuhnya teologi naturalisme modern, dalam the world University Encyclopedia vol. 11, dijelaskan bahwa: "Theology, term employed by classical authors to describe tratise on the nature and worship of gods such as Hesiod's work and Dogs, and Cicero's Natura Deorum. It is now applied to the science which treats of God and man, and has special reference to the present condition and ultimate destiny of mankind"s.

(Teologi, satu istilah yang dipergunakan oleh penulis-penulis klasik untuk menguraikan kajian tentang alam dan penyembahan kepada dewa-dewa, seperti buku "hesiods "works dan dogs" dan bukunya Cicero "natura Deorum". Sekarang dipakai oleh ilmu pengetahuan yang berkaitan dengan Tuhan dan manusia dan berujukan khusus dengan keadaan masa kini dan tujuan akhir daripada manusia).

Berdasar berbagai penjelasan di atas, terlihat bahwa asalusul tumbuhnya teologi naturalisme merupakan pengaruh dari perkembangan alam pikiran dan pengetahuan manusia yang terjadi lebih kurang pada abad atau masa renaissance (abad 15-16) yang didorong oleh keinginan intelektual untuk menyelaraskan permasalahan agama dengan pengetahuan manusia yang sesuai dengan rasio atau akal. Namun pada kenyataannya keinginan itu tidak membuahkan hasil, malah justru sebaliknya, karena ternyata isi kitab suci yang mereka akui tidak dapat menjelaskan dan mengembangkan rasionalitas dalam mengkaji tentang kejadian

${ }^{2}$ Elias A. Elias, Elias' Modern Dictionary English Arabic, (Kairo: Elias Moders Press, 1968), h. 84.

${ }^{3}$ Hasbullah Bakry, Sistematika Filsafat, (Jakarta: Wijaya, 1986), h. 60.

${ }^{4}$ Lewis Muford, ad, New Masters Pictorial Encyclopedia Vol. VIII, (New York Washington DC: Books Inc, Publishers-Asubdiary of Publishers Co. Inc., tt), h. 1335.

${ }^{5}$ The World University, Encyclopedia, vol. 11, (Washington DC: Straichvertaire Publisher Company inc, 1965), h. 4996. 
alam dan mengolahnya dengan akal manusia. Keadaan yang demikian itu akhirnya menimbulkan reaksi yang keras terhadap agama yang dianggap sebagai penghambat bagi kemakmuran hidup manusia. Dalam pada itu Yusuf Karom dalam bukunya Falsafah al Hadisah mensinyalir sebagai berikut :

"Jika diperhatikan ternyata bertambah hebatnya gerakan ilmiah yang terjadi pada awal abad XVII merupakan reaksi terhadap pemikiran masa skolastik. Pemahaman agama yang tidak rasional dan tidak logis mendorong bangkitnya di lingkungan itu sendiri suatu gerakan ilmiah dan pemikiran baru yang bebas daripada doktrin agama yang dianggap tidak relevan dengan hasil penemuan akal manusia dalam bidang ilmu pengetahuan. Pilihan paling tepat adalah berpikir bebas serta membentuk ilmu-ilmu baru seperti; ilmu pasti dan ilmu alam dengan melepaskan diri dari ikatan agama yang jelas tidak selaras dengan apa yang dipelajari dan selidiki. Gerakan ini bersumber dari logika yang sama bagi lahirnya filsafat modern. Pengaruh gerakan ini masih berlangsung sampai sekarang dalam bidang ilmu pengetahuan dan filsafat serta ide-ide pemikiran lainnya. Tokoh-tokoh gerakan tersebut antara lain adalah F. Bacon, Thomas Hobbes, Spinoza dan termasuk Nietzsche, Libnis, Pascal dan Malebranche. ${ }^{6}$

Berbagai pengertian dan asal usul teologi naturalisme di atas, maka dapat dipahami bahwa yang dimaksud dengan teologi naturalisme ialah pokok pemikiran kaum naturalis terhadap eksistensi Tuhan, agama dan semua yang bersifat spiritual metafisik lainnya yang disandarkan semata-mata pada alam lahiriyah dan kemampuan akal manusia. Secara filosofis pemberi lahan subur atau dorongan bagi tumbuh dan berkembangnya teologi naturalisme modern terkait dengan empat faktor: Pertama, karena keinginan para pemikir Barat untuk menselaraskan permasalahan agama dengan hasil pengetahuan yang sesuai dengan akal manusia. Kedua, karena isi kitab suci Kristen dianggap tidak dapat menyelesaikan permasalahan-permasalahan yang dihadapi oleh umat manusia. Ketiga, pengaruh perkembangan alam pikiran dan pengetahuan manusia pada abad pertengahan (skolastik) adalah stagnan dan keempat, karena dogma-dogma agama yang bersifat dogmatis serta

`Yusuf Karom, Tarīkhul Falsafah al-Hadìsah, (Kairo: Dār al-Ma’ārif, tt.), h. 43. 
kekuasaan gereja yang absolut, maka terdoronglah para pemikir Barat modern untuk membebaskan diri dari ikatan Tuhan dan agama.

Tegasnya dapat dikatakan bahwa secara esensial paham teologi naturalisme modern dapat dikatakan muncul sebagai kritik dan sekaligus wujud dari kekecewaan para pemikir Barat modern terhadap pemikiran filsafat abad pertengahan yang dianggap tidak dapat memuaskan keinginan manusia. Paradigma pemikiran filsafat abad pertengahan pada kenyataannya memang didominasi dan bersandar pada agama yang dipelopori oleh kaum gereja. Hal semacam itu dipandang sangat mengganggu atau sangat menghalangi bagi kebebasan manusia dalam pengembangan ilmu pengetahuan dan teknologi. Kritik dan kekecewaan para pemikir Barat modern tersebut tentunya sangat beralasan, karena fakta sejarah menunjukkan pada sekitar abad ke-8 hingga ke-12 Masehi dunia Barat praktis mengalami abad kegelapan. Akhirnya para pemikir Barat modern antara lain seperti ${ }^{7}$ "Baruch Spinoza, John Locke, Ludwig Feurbach, John Dewey, Karl Marx, William James, Friedrich Niezsche dan lainnya berupaya untuk menyingkirkan agama dan semua hal-hal yang bersifat spiritual metafisik dari ranah berpikir dan kehidupan praktis manusia.

Tokoh pemikir pertama filsafat alam adalah Thales yang dilahirkan di Meletos kira-kira tahun 624-548 SM. Inti filsafatnya adalah bahwa asas pertama dari segala yang ada adalah air yang dapat dijumpai dalam berbagai wujud baik sebagai benda padat maupun benda cair dan gas (es, air, uap) ${ }^{8}$. Aristoteles yang dikutip oleh Muhammad Hatta berkesimpulan bahwa ajaran Thales pada mulanya didapatkan melalui proses berfikir tentang apa asal alam ini dan apa yang menjadi sebab penghabisan dari pada segala yang ada ini ${ }^{9}$ (awal dan akhir dari segala yang ada). Berdasarkan hasil petualangannya sehari-hari, Thales melihat betapa air laut menjadi sumber hidup dan betapa masyarakat Mesir nasibnya sangat tergantung kepada sungai Nil. Thales juga melihat air laut itu dapat

${ }^{7}$ K. Bertens, Panorama Filsafat Modern, (Jakarta: Gramedia, 1987), h. 90-91.

${ }^{8}$ M.A.W. Brouwer, \& M. Puspa Heryadi, Sejarah Filsafat Barat Modern dan Sezaman, (Bandung : Alumni, 1986), h. 3.

${ }^{9}$ Muhammad Hatta, Alam Pikiran Yunani, (Jakarta: Tinta Mas, 1986), h. 7. 
menggulung dan menghanyutkan ${ }^{10}$. Air yang dimaksud oleh Thales itu merupakan satu-satunya syarat bagi proses perkembangan segala yang ada dan air itu mempunyai energi atau ruh sebagaimana besi berani. Adrongi mengutip buku On First, mengemukakan bahwa pemikiran Thales yang sangat terkenal adalah asas pertama dari segala sesuatu berasal dari dan akan kembali kepada air ${ }^{11}$.

Tokoh filsafat alam setelah Thales adalah Anaximandros (610 - 540 SM), tokoh ini justru mengkritik pokok pemikiran Thales, karena menurut Anaximandros air tidak dapat dikatakan sebagai asas pertama dari alam semesta. Asas pertama dari kesemestaan yang benar adalah "to apeiron" (yang tidak terbatas) dan asas itu disebut demikian karena tidak memiliki sifat-sifat benda yang dikenal oleh manusia ${ }^{12}$. Dalam teori Anaximandros dijelaskan bahwa terjadinya alam dunia ini disebabkan oleh perceraian, dan perceraian itu dari to apeiron yang dilepaskan oleh anasir-anasir yang saling berlawanan, yaitu seperti panas dan dingin, kering dan basah dan sebagainya. Perceraian tersebut mengakibatkan adanya gerak puting beliung yang memisahkan antara dingin dan panas, yang panas kemudian membalut yang dingin dan yang dingin berada di tengah-tengah yang panas. Gerak puting beliung itu juga mengakibatkan terjadinya suatu bola raksasa, oleh karena panas itu air lepas dari pada tanah dan lalu menjadi kabut. Sedangkan udara menekan bola raksasa sedemikian rupa hingga meletus menjadi sebuah lingkaran yang berpusat satu. Peristiwa itu menurut Anaximandros, menunjukkan setiap lingkaran terdiri dari api yang dibalut udara, sedangkan setiap lingkaran memiliki satu lobang yang menjadi api dan di dalamnya tampak sebagai bintang-bintang, bulan dan matahari ${ }^{13}$. Menurut Anaximandros di dalam dunia ini ada hukum keseimbangan, sehingga Anaximandros menyimpulkan bahwa, dalam arche masih terkumpul sifat-sifat yang berlawanan pada kesatuan yang tidak tertentu dan gerakan yang melingkar dari alam semesta menyebabkan bumi melayang-layang di tengahtengahnya ${ }^{14}$. Di samping itu Anaximan-dros juga percaya bahwa

${ }^{10}$ Ibid, h. 7.

${ }^{11}$ Adrongi, Filsafat Alam Semesta, (Kebumen: Bintang Pelajar, 1986), h. 59.

${ }^{12}$ Hadiwiyono, Sari Sejarah..., h. 17.

${ }^{13}$ Ibid, h. 17.

${ }^{14}$ A. Epping O.F.M, (ed.), Filsafat Ensie, (Bandung: Jemmars, 1983), h. 16 
terdapat bilangan kosmos yang tidak terbatas dan proses penciptaan kearah sebuah kesatuan yang terbatas serta proses penciptaan kearah sebuah kesatuan yang tertib tidak akan pernah berhenti dan itu terjadi melalui evolusi. Pokok pemikiran Anaximandros yang semacam inilah, maka kemudian dia dikenal sebagai bapak evolusi ${ }^{15}$. Ringkasnya To apeiron itu adalah satu, namun satu itu bukanlah air tetapi ia tidak berhingga dan tidak berkeputusan serta ia tidak dapat dirupakan dengan sesuatu yang ada di dunia ini ${ }^{16}$. Bumi ini bermula dibalut oleh uap yang basah dan karena bumi berputar maka yang basah menjadi kering secara berangsur-angsur, akhirnya tinggallah sisa uap yang basah sebagai laut pada bumi dan karena bumi ini pada mulanya diliputi air semata-mata, maka makhluk pertama di atas bumi ialah hewan yang hidup di dalam $\operatorname{air}^{17}$.

Setelah Anaximandros, tokoh filsafat alam berikutnya adalah Anaximenes (538-480 SM). Filsafat Anaximenes menyimpulkan bahwa asas pertama alam ini adalah "udara”, karena itu udaralah yang menjadi induk segala sesuatu ${ }^{18}$. Manusia akan mati apabila tidak ada udara dan hal ini dapat dibuktikan melalui argumentasinya yang dikutip oleh Harun Hadiwiyono; "Bukankah udara itu yang menjadikan manusia hidup dan bukankah udara itu meliputi seluruh jagat raya, manusia akan mati apabila tidak bernapas, maka udara itulah yang melahirkan segala benda di dalam jagat raya. Karena udara memadat, maka timbullah secara berturut-turut air, angin, tanah dan batu, kemudian sebaliknya karena udara encer atau cair, maka timbullah api, demikianlah dari udara itu terjadinya anasir-anasir yang membentuk jagat raya dan seluruh isinya ${ }^{19}$.

Berbeda dengan Anaximandros, Anaximenes tidak dapat menerima barang asal itu yang tidak dapat dirupakan, sebab menurutnya asal itu mestilah satu dan tampak ${ }^{20}$. Dengan demikian udara yang dimaksudkan adalah berwujud benda atau materi yang dapat disamakan dengan barang yang lain yang nampak oleh panca

\footnotetext{
${ }^{15}$ Adrongi, Filsafat...., h. 62.

${ }^{16}$ Hatta, Alam..., h. 9.

${ }^{17} \mathrm{Ibid}, \mathrm{h} .11$.

${ }^{18}$ Brouwer, Heryadi, Sejarah...., h. 3.

${ }^{19}$ Hadiwiyono, Sari Sejarah..., h. 18.

${ }^{20}$ Hatta, Alam...., h. 12.
} 
indera manusia. Phytagoras (580 SM) juga andil dalam pengkajian tentang asas pertama alam semesta ini, di mana inti filsafatnya menunjukkan bahwa asas pemula kejadian alam adalah bilangan, terutama bilangan satuan. Seluruh kenyataan ini didasarkan atas bilangan-bilangan dan bilangan merupakan keseluruhan yang teratur dalam $\operatorname{kosmos}^{21}$. Karena bilangan merupakan asal dari segala realitas dan realitas terdiri dari titik-titik yang mempunyai sifat homogen, maka semua yang ada akan berakhir dan tunduk kepada bilangan ${ }^{22}$.

Selain para filosof alam di atas, masih banyak filosof-filosof alam lainnya antara lain seperti Empedokles, Anaxagoras, Leukippos dan Demokritos yang pada intinya filsafat mereka tidak jauh berbeda dari filsafat alam sebelumnya. Empedokles yang hidup (490 - 430 SM) misalnya, berkesimpulan bahwa alam tersusun dari anasir asal yang jumlahnya empat, yaitu "udara, api, air dan tanah". Keempat anasir tersebut memangku sifatnya masing-masing yaitu dingin, panas, basah dan kering ${ }^{23}$ dan alam ini pada awalnya bercampur jadi satu karena kodrat cinta. Kemudian terjadi pemisahan. Percampuran dan pemisahan itu disebabkan oleh dua dasar yang berada di luar, yaitu "cinta dan benci". Anaxagoras yang hidup (500 - $428 \mathrm{SM}$ ), baginya anasir asal itu bukan empat, tetapi banyak atau tak terhingga dan tidak bisa berubah-ubah, oleh karenanya anasir asal itu mestilah ada pada setiap barang. Kebendaan diwujudkan oleh kesatuan-kesatuan yang kecil dan tidak terhingga dan masingmasingnya adalah campuran dari "tebal dan tipis, basah dan kering, panas dan dingin, gelap dan terang dan seterusnya" 24 .

Leukippos, Demokritos dan juga Epicurus, ketiga tokoh ini mempunyai pandangan yang sama tentang alam semesta ini. Leukippos yang mengajarkan bahwa tiap-tiap benda terjadi daripada perhubungan atom ${ }^{25}$. Kemudian inti filsafat Demokritos adalah "alam semesta ini berawal dan berakhir kepada atomatom dan atom itu tak bermula dan tak berakhir, ia ada selama-

\footnotetext{
${ }^{21}$ Bernard Delfgauw, Sejarah Ringkas Filsafat Barat, terj. Soejono Soemargono, (Yogyakarta: Tiarawacana, 1992), h. 5.

${ }^{22}$ Brouwer, Heryadi, Sejarah...., h. 4.

${ }^{23}$ Hatta, Alam...., h. 36.

${ }^{24}$ Epping, Filsafat...., h. 85.

${ }^{25}$ Hatta, Alam..., h. 43.
} 
lamanya. Relevan halnya dengan Epicurus (324 - 270 SM), di mana filsafatnya menyimpulkan bahwa tidak ada kenyataan selain daripada kenyataan yang dibangun atas dasar atom yang bersifat kebendaan ${ }^{26}$. Demikian karakteristik dan inti pemikiran sebahagian besar filosof alam pada zaman Yunani. Kemudian pemikiran tersebut sangat mempengaruhi dan dikembangkan oleh para filosof alam zaman modern dan sekaligus bermuara pada pemikiran teologi naturalisme.

\section{Pokok-Pokok Pemikiran Teologi Naturalisme}

Pada zaman renaissance dan aufklarung umumnya yang berkuasa ialah semangat yang menaruh kepercayaan optimistik pada kekuatan akal manusia, terutama di daratan Eropa dan Amerika. Misalnya saja ketika Spinoza menyimpulkan bahwa alam semesta ini laksana suatu sistem matematika dan dapat dijelaskan secara rasional (apriori) dengan cara mendeduksi aksioma-aksioma. Oleh karena itu tidaklah mengherankan ketika Hobbes meningkatkan rasionalitas itu menjadi materialisme dan ateisme yang nonkompromis. ${ }^{27}$ Berbarengan dengan zaman itu perkembangan ilmu pengetahuan sangat mengagumkan terutama ilmu alam atau ilmu pasti seperti fisika, kimia dan biologi. Peletak dasar dari ilmuilmu alam itu antara lain adalah Isaac Newton dan dilanjutkan oleh para pengikutnya.

Sesuai dengan metode Newton dalam menyelidiki alam yang bersifat organis, maka filsafat juga menggunakan metode induksi, di mana orang berpangkal pada gejala-gejala khusus dan mencoba mengembalikannya kepada beberapa asas dan hukum yang bersifat umum $^{28}$. Pemikiran filsafat Newton jika dilihat dasar ontologisnya, maka filsafatnya identik dengan paham deisme yang muncul pada abad XVII di Inggris. Inti dari paham deisme adalah, bahwa setelah Tuhan menciptakan alam semesta ini maka Tuhan pergi jauh di luar alam atau Tuhan tidak ikut campur lagi di dalam alam ${ }^{29}$

\footnotetext{
${ }^{26}$ Epping, Filsafat..., h. 111.

${ }^{27}$ Ahmad Tafsir, Filsafat Umum Akal dan Hati dari Thales sampai James, (Bandung: Remaja Rosdakarya, 1993), h. 103.

${ }^{28}$ Hadiwiyono, Sari Sejarah..., h. 48.

${ }^{29}$ Zubaidi Mastal, PTM, Theisme dan Anti Theisme, (Lampung: Fak. Ushuluddin IAIN Raden Intan, 1993), h. 56.
} 
(alias Tuhan memasuki usia pensiun). Secara esensial paham deisme menggabungkan diri dengan gagasan Eduard Herbert (1581 - 1648) yang berkesimpulan bahwa "akal manusia mempunyai otonom mutlak di bidang agama, juga agama Kristen harus ditaklukkan kepada akal. Dalam segala agama yang positif menurutnya terdapat kebenaran-kebenaran alamiah ${ }^{30}$ dan paham ini sangat menentang agama wahyu.

Secaraumum dapatdipahami,pokok-pokokpemikiran teologi naturalisme ${ }^{31}$ menganggap bahwa alam semesta ini selain sudah memiliki hukum-hukum yang pasti, juga alam sudah sempurna dan tidak perlu lagi adanya campur tangan sang pencipta atau Tuhan. Selanjutnya alam semesta ini menjadi dan menjadi dengan sendirinya menurut tabiat atau berdasarkan hukum sebab-akibat (hukum kausalitas). Louis Leahy mengemukakan bahwa pandangan yang seperti itu meskipun mencirikan filsafat ketuhanan, namun orang akan melihat rasionalitas ini sama sekali tidak menuntut aspirasi dari dimensi religius manusia dan akibatnya terjadilah pemisahan antara Tuhan dalam agama yang sebenarnya dengan kehidupan manusia ${ }^{32}$ (Suatu paham yang disebut sekularisme).

Relevan dengan pandangan tersebut di atas, Kattsoff juga menjelaskan bahwa menurut naturalisme, alam semesta dan manusia bergerak atau berjalan dengan sendirinya dan semuanya bersifat kekal. Naturalisme juga secara terbuka menolak tentang adanya adialami atau super-natural. Alam semesta dipahami sebagai suatu tatanan yang mekanistik atau setidak-tidaknya suatu tatanan yang bukan bersifat kesusilaan ${ }^{33}$. Naturalisme menganggap kehidupan manusia yang bersifat kesusilaan adalah suatu perbuatan yang berhubungan dengan sesuatu yang bersifat alamiah dan agar kesusilaan itu dapat berlaku, maka tidak diperlukan adanya Tuhan yang sudah berada di luar alam dunia, atau suatu jiwa yang bersifat

${ }^{30}$ Hadiwiyono, Sari Sejarah ..., h. 49.

${ }^{31}$ Zubaidi Mastal, Perkembangan Teologi Modern 2, Materialisme dan Sekularisme, (Lampung: Fak. Ushuluddin IAIN Raden Intan, 1992), h. 34.

${ }^{32}$ Louis Leahy, SJ, Filsafat Ketuhanan Kontemporer, (Yogyakarta: Kanisius, 1993), h. 19.

${ }^{33}$ Louis Kattsoff, Pengantar Filsafat, Terj. Soejono Soemargono, (Yogyakarta: Tiarawacana, 1992), h. 117. 
adi-alami. ${ }^{34}$ Singkatnya menurut naturalisme kehidupan manusia yang baik dan benar adalah kehidupan manusia yang dalam perbuatan dan prilakunya harus sesuai dengan kodrat alamiah manusia itu sendiri. Pokok-pokok pemikiran teologi naturalisme kemudian selanjutnya meningkat menjadi teologi atheisme atau suatu paham yang anti Tuhan. Inti dari pandangan teologi ateisme, bahwa sesungguhnya tidak ada yang disebut Tuhan, adanya Tuhan tidak masuk akal dan tidak dapat dibuktikan secara rasional dan empiris. ${ }^{35}$

Sekilas gambaran pokok-pokok pemikiran teologi naturalisme tersebut di atas, secara filosofis dapat diinterpretasikan bahwa; eksistensi manusia dan alam semesta tidak lagi memerlukan keterlibatan atau tidak ada kaitannya dengan Tuhan, karena manusia dan alam semesta tanpa intervensi Tuhan pun dapat hidup layak dan dapat berjalan sebagaimana mestinya. Demikian pula halnya agama yang mengajarkan adanya metafisika, super-natural atau adi-alami tidak mempunyai arti apa-apa bagi kehidupan praktis manusia. Menurut teologi naturalisme semua hal-hal tersebut sangat berten-tangan dengan kodrat alamiah manusia yang sesungguhnya, kalaupun agamayangdianggapbenaradalah agamayangmempunyai kebenaran alamiah, sehingga seluruh rangkaian kehidupan manusia harus berfokus dan berorientasi kepada kebenaran alamiah semata. Singkatnya teologi naturalisme menganggap kehidupan praktis manusia tidak ada kaitannya dengan Tuhan, agama, kesusilaan dan segala sesuatu yang bernuansa metafisik dan spiritual.

Sebelum mengkaji implikasi teologi naturalisme terhadap pradaban manusia kontemporer, terlebih dahulu akan disinggung walaupun hanya sekilas kritik Islam atas pokok-pokok teologi naturalisme tersebut. Hal ini dimaksudkan agar dapat dipahami bahwa konsep ketuhanan, agama dan segala sesuatu yang bernuansa metafisik-spiritual dalam Islam secara implisit dan eksplisit tidaklah sama atau terdapat perbedaan yang signifikan dengan agama Kristen yang dituduh sebagai penghambat kebebasan manusia dalam pengembangan intelektualitas.

${ }^{34}$ Ibid, h. 117.

${ }^{35}$ Mastal, Perkembangan ..., h. 34. 


\section{Kritik Islam Terhadap Pokok-pokok Pemikiran Teologi Naturalisme}

Sekilas pandangan teologi naturalisme yang telah diuraikan di atas, sesungguhnya sangat berbeda dengan konsep ke-Tuhanan dan agama dalam Islam. Bahwa dalam Islam yang menciptakan dan sekaligus mengatur serta memelihara seluruh makhluk kesemestaan adalah Tuhan secara mutlak. Tuhan dalam pandangan Islam adalah Maha Esa, Maha Sempurna dan hanya kepada-Nya segala sesuatu berawal dan juga akan berakhir serta Tuhan tidak pernah sama dengan makhluk-makhluk ciptaan-Nya (alam). Seperti dikemukakan oleh Arifin Bey, bahwa saripati ajaran semua Nabi dan Rasul, semenjak Nabi Adam sampai Nabi Muhammad adalah untuk mengakui tidak ada Tuhan yang benar kecuali Allah swt dan kepada-Nya segala sesuatu bergantung ${ }^{36}$. Sedangkan penciptaan dan keberadaan atau eksistensi manusia mempunyai tujuan yang jelas, yaitu untuk mengabdikan diri kepada Tuhan sang pencipta, bahkan keberadaan manusia di dunia ini merupakan bagian dari realitas kesemestaan, maka manusia didudukkan sebagai khalifah atau wakil Tuhan di bumi. Kemudian secara reflektif berbagai tujuan dan tugas manusia tersebut tidak mungkin dapat dilaksanakan dengan baik dan benar kecuali dengan petunjuk dan bimbingan dari yang menciptakan dan menugaskannya yaitu Tuhan. Berkaitan degan pencapaian tujuan dan pelaksanaan tugas manusia itulah maka Tuhan mengirimkan atau mengutus manusia-manusia pilihan untuk menyampaikan petunjuk (sebagai salah satu wujud intervensi Tuhan) kepada manusia dan seluruh realitas kesemestaan. Petunjuk Tuhan yang disampaikan melalui para Nabi itulah yang disebut agama. Artinya agama (Islam) adalah sesuai dengan fitrah, kodrat dan hakikat manusia serta kebenarannya tidak pernah bertentangan dengan kehidupan manusia.

Islam diturunkan Tuhan bertujuan untuk rahmat bagi seluruh makhluk kesemestaan, dalam pengertian mengadanya Islam itu adalah untuk mengangkat harkat dan martabat manusia dari suatu maqom kejahiliyahan menuju kepada kemanusiaan yang seutuhnya. Ringkasnya dapat dikatakan bahwa Islam sebagai agama secara aksiologis bertujuan untuk membangun

${ }^{36}$ Bey Arifin, Mengenal Tuhan, (Surabaya: Bina Ilmu, 1961), h. 32. 
kerohanian dan kejasmanian (spiritual dan material) dan juga untuk mengembangkan intelektual dan intelegensia manusia secara holistik, totalitas dan mendasar. Relevan dengan pandangan tersebut, Abdul Hakim menegaskan bahwa Islam yang berarti damai atau berserah diri bertujuan untuk menjadi rahmat bagi seluruh kehidupan alam dan manusia ${ }^{37}$. Di dalam al-Quran Tuhan mensinyalir bahwa hamparan alam semesta adalah diperuntukkan bagi kehidupan manusia sepenuhnya. Oleh karena itu Tuhan memerintahkan kepada manusia agar tidak hanya mengeksploitasi kekayaan alam, tetapi sekaligus memperhatikan, menghormati dan melestarikan alam raya secara sungguh-sungguh dan terus menerus, supaya seluruh umat manusia dapat merasakan manfaatnya, baik manfaat yang bersifat material maupun manfaat yang bersifat spiritual dan bahkan untuk dapat menghantarkan manusia kepada suatu kesadaran akan adanya Tuhan Yang Maha Esa dan ke-Maha Kuasaan Tuhan (intervensi) terhadap seluruh makhluk kesemestaan ${ }^{38}$.

Berdasarkan berbagai uraian di atas, dapat dipahami bahwa Tuhan dan agama, kaitannya dengan alam dan manusia dalam perspektif Islam merupakan satu rangkaian yang tidak dapat dipisahkan, karena satu dengan lainnya saling memaknai, saling menguatkan dan saling ketergantungan, artinya jika salah satunya diabaikan atau direduksikan dari ranah kehidupan manusia dan alam, maka dapat dipastikan akan terjadi ketidakseimbangan dalam kehidupan umat manusia itu sendiri.

\section{E. Implikasi Teologi Naturalisme Terhadap Kehidupan Manusia Kontemporer}

Secara implisit, implikasi teologi naturalisme terhadap kehidupan manusia kontemporer telah tergambar pada uraian sebelumnya, di mana semenjak kemunculannya sebagai paham kefilsafatan, hampir semua peradaban barat modern diwarnai oleh paham naturalisme. Hal itu harus diakui, bahwa kebebasan berpikir

\footnotetext{
${ }^{37}$ Khalifah Abdul Hakim, Hidup Yang Islami, Menyeharikan Pemikiran Transendental Aqidah dan Ubudiyah, terjemahan Machmud Husein, (Jakarta: Rajawali, 1986), h. 115.

${ }^{38}$ M. Quraish Shihab, Membumikan al-Qur'an, (Bandung: Mizan, 1992), h. 132.
} 
sebelum munculnya paham naturalis, di dunia barat masih terjerat oleh kejumudan bahkan kemandegan atau stagnan. Sebagaimana telah dikemukakan bahwa fakta historis menunjukkan lebih kurang pada abad ke-8 hingga abad ke-12 Masehi dunia barat praktis mengalami abad kegelapan. Kenyataan semacam itu ditengarai sebagai akibat dari doktrin-doktrin gereja yang menentang pengembangan rasionalitas umat manusia. Kemudian setelah lahirnya gerakan renaissance dan aufklarung disekitar abad ke-1517 Masehi barulah peradaban dunia barat mengalami pencerahan dan beranjak dari keterpurukannya. Kenyataan ini sekaligus menunjukkan dimulainya era modern.

Perkembangan peradaban dan pemikiran barat pada era modern secara faktual memang banyak membawa kemajuan yang luar biasa, terutama dalam bidang ilmu pengetahuan dan teknologi, namun harus diakui pula bahwa kemajuan itu hanya pada tatanan fisik material yang akhirnya menimbulkan kegalauan dan kegamangan yang menggelisahkan kehidupan umat manusia kontemporer. Hadari Nawawi ${ }^{39}$ menjelaskan bahwa kehidupan modern telah menghasilkan ilmu pengetahuan dan teknologi yang sangat spektakuler dan telah melahirkan nilai-nilai baru dalam kehidupan umat manusia. Namun gejala semacam itu menunjukkan adanya kecenderungan globalisasi nilai-nilai, baik nilai yang bersifat spiritual, moral maupun sosial. Menurut Hadari Nawawi kenyataan seperti itu sekaligus menggambarkan bahwa abad modern akan menimbulkan krisis nilai-nilai spiritual dan moral yang hakiki dalam kehidupan manusia kontemporer. Hal itu ditandai dengan banyaknya perenungan atau pemikiran yang berujung pada perumusan pandangan hidup yang tidak bersandar pada pengakuan akan keberadaan Tuhan. Paradigma kehidupan semacam ini pada mulanya banyak terjadi di benua Eropa dan Amerika kemudian masuk ke Rusia dan Cina berkembang menjadi sosialisme-komunisme dan atheisme. Dapat ditambahkan pula bahwa pada era kontemporer paradigma tersebut sudah merambah keseluruh dunia termasuk Indonesia.

\footnotetext{
${ }^{39}$ Hadari Nawawi, Hakekat Manusia Menurut Islam, (Surabaya: al-Ikhlas, 1993),
} h. 310 . 
Faisal Ismail ${ }^{40}$ mengemukakan hilangnya pengakuan akan Tuhan, agama dan nilai-nilai spiritual metafisik lainnya dari ranah peradaban kehidupan manusia, wajah peradaban manusia menjadi tercabik-cabik, tanpa sandaran yang hakiki dan tanpa muatan nilai-nilai ke-Tuhanan dan keagamaan. Konsekuensinya adalah banyak terjadi tindakan kekerasan, keberingasan dan keberutalan. Serangkaian pembataian sadis, tawuran antar pelajar, antar mahasiswa, penodongan dan perampokan serta berbagai bentuk kejahatan lainnya yang telah menelan korban jiwa dan mengancam ketenangan hidup umat manusia. Tidak hanya itu Faisai Ismail menambahkan, bahwa implikasi atau dampak dari ketidak hadiran Tuhan dan agama dalam kehidupan umat manusia, kearifan dan kesantunan sebagian pemimpin negeri ini telah pudar, seperti manipulatif, kamuflase, pembohongan publik atau tindakan yang mengelabui masyarakat.

Tersingkirnya spiritualitas, religiusitas dan moralitas sebagai-mana dalam teologi naturalisme, sudah pasti juga akan berimplikasi pada hilangnya rasa kebersamaan, rasa kesamaan, rasa kekeluargaan dan rasa keadilan, dan justru yang dominan menguasai peradaban umat manusia kontemporer adalah prilaku yang didorong oleh nafsu individualistik, kapitalistik dan hedonistik, yaitu suatu sikap yang mementingkan diri sendiri dan kelompok, sikap suka menindas kaum yang lemah dan selalu mengutamakan kenikmatan praktis tanpa mempedulikan solidaritas dan sosialitas. Sikap hidup ateis praktis atau sekularisme yang memisahkan antara urusan dunia dan nilai-nilai ketuhanan, religiusitas keagamaan dan spiritual metafisik adalah bentuk paling moderat dari implikasi teologi naturalisme, sedangkan bentuk eksrimnya adalah ateisme yang mematikan Tuhan dari kehidupan manusia (puncak dari implikasi teologi naturalisme).

Secara faktual sikap hidup atheis praktis atau yang identik dengan sekularisme telah menjamur di Indonesia. Tampilan karakterik kehidupan sekularisme dan atheisme telah mewarnai hampir seluruh sendi kehidupan anak bangsa ini. Selain prilaku kekerasan dan kebrutalan sebagaimana telah disebutkan di atas,

\footnotetext{
${ }^{40}$ Faisal Ismail, Pencerahan Spiritualitas Islam di Tengah Kemelut Zaman Edan,(Yogyakarta: Titian Wacana, 2008), h. 108-109.
} 
tindakan korupsi, sikap egoistik dan individualistik telah merasuki sebagian besar penduduk negeri ini. Sebagian besar pemimpin dan masyarakat bangsa ini seakan bangga dengan berbagai tindakan yang tidak berperikemanusiaan semacam itu. Hal ini dapat dibuktikan bahwa persoalan korupsi bukan hanya terkait dengan pejabat publik saja, tetapi juga sudah menjadi persoalan setiap orang yang menyalah gunakan kedudukannya demi memperoleh keuntungan dengan mudah dan semata-mata untuk kenikmatan pribadi dan golongannya ${ }^{41}$. Contoh paling konkret di Indonesia akhir-akhir ini adalah, penerimaan sebagian pegawai negeri yang harus memakai uang pelicin (suap), pengangkatan sebagian pejabat publik harus dengan setoran sejumlah uang, perusahaan untuk mendapatkan proyek tertentu juga tidak terlepas dari setoran semacam itu, sehingga tidak mengherankan kalau Gayus Tambunan yang baru seumur jagung menjadi pegawai negeri sudah menumpuk uang miliaran rupiah dari hasil perbuatan keji, haram dan tercela yaitu korupsi. Ringkasnya dapat dikatakan bahwa semua prilaku manusia yang tidak berprikemanusiaan tersebut adalah akibat dari matinya hati nurani manusia dan keringnya nilai-nilai ketuhanan, religiusitas dan spiritual metafisik dari berbagai kreativitas dan aktivitas kehidupan umat manusia. Keterputusan hubungan manusia dengan Tuhan dan agama (religiusitas), spiritual metafisik secara esensial filosofis dapat dipastikan adalah implikasi dari teologi naturalisme.

\section{F. Penutup}

Teologi naturalisme secara faktual telah banyak menimbulkan implikasi terhadap kehidupan manusia, baik implikasi yang positif seperti bangkitnya rasionalitas manusia dalam mengembangkan ilmu pengetahuan dan teknologi. Kemajuan ilmu pengetahuan dan teknologi memang harus diakui telah berhasil menghantarkan kehidupan manusia sampai pada tatanan hidup yang sangat mengagumkan dan membahagiakan, terutama dalam bidang komunikasi dan transformasi. Namun kemajuan tersebut pada kenyataannya hanya terbatas pada sisi material semata,

${ }^{41}$ Himyari Yusuf, Filsafat Di Balik Problematika Kehidupan, (Bandar Lampung: Pusikamla, 2009), h. 63-64. 
sementara pada sisi ketuhanan dan religiusitas, spiritual, metafisik dan moral sangat memperihatinkan. Karakteristik kehidupan yang melepaskan Tuhan dan agama serta hal-hal yang metafisik dari ranah kehidupan merupakan inti dan orientasi paling utama dari paham teologi naturalisme, maka paradigma peradaban manusia kontemporer yang sadisme, anarkhisme, egoisme, individualisme dan berbagai per-buatan kotor lainnya secara esensial filosofis adalah implikasi yang luar biasa dari teologi naturalisme. [ ]

\section{Daftar Pustaka}

Adrongi, Filsafat Alam Semesta, Kebumen: Bintang Pelajar, 1986.

Arifin, Bey, Mengenal Tuhan, Surabaya: Bina Ilmu, 1961.

Bakry, Hasbullah, Sistematika Filsafat, Jakarta: Wijaya, 1986.

Bertens, K., Panorama Filsafat Modern, Jakarta: Gramedia, 1987.

Brouwer, M.A.W., \& Heryadi, M. Puspa, Sejarah Filsafat Barat Modern dan Sezaman, Bandung: Alumni, 1986.

Delfgaauw, Bernard, Sejarah Ringkas Filsafat Barat, terj. Soejono Soemargono, Yogyakarta: Tiarawacana, 1992.

Elias, Elias A., Elias' Modern Dictionary English Arabic, Kairo: Elias Modern Press, 1968.

Hadiwiyono, Harun, Sari Sejarah Filsafatbarat1, Yogyakarta: Kanisius, 1990.

, Sari Sejarah Filsafat Barat 2, Yogyakarta: Kanisius, 1990.

Hakim, Khalifah Abdul, Hidup Yang Islami, Menyeharikan Pemikiran Transendental Aqidah dan Ubudiyah, terj. Machmud Husein, Jakarta: Rajawali, 1986. M., A. Epping O. F., et.all., Filsafat Ensie, Bandung: Jemmars, 1983.

Hatta, Muhammad, Alam Pikiran Yunani, Jakarta: Tintamas, 1986.

Karom, Yusuf, Tarīkh al-Falsafah al-Hađisaah, Kairo: Dār al-Ma'arif, tt.

Kattsoff, Louis, Pengantar Filsafat, Terjemahan Soejono Soemargono, Yogyakarta: Tiarawacana, 1992. 
Leahy, Louis, SJ, Filsafat Ketuhanan Kontemporer, Yogyakarta: Kanisius, 1993.

Mastal, Zubaidi, PTM. Theisme dan Anti Theisme, Lampung: Fak. Ushuluddin IAIN Raden Intan, 1993. ,Perkembangan Teologi Modern 2, Materialisme dan Sekularisme, Lampung: Fak. Ushuluddin IAIN Raden Intan, 1992.

Muford, Lewis, (ed), New Masters Pictorial Encyclopedia Vol. VIII, New York - Washington DC: Books Inc. Publishers-Asubdiary of Publishers Co. Inc., , tt. Nawawi, Hadari, Hakekat Manusia Menurut Islam, Surabaya: al-Ikhlas, 1993.

Shihab, M. Quraish, Membumikan al-Qur'an, Bandung: Mizan, 1992.

Tafsir, Ahmad, Filsafat Umum Akal dan Hati dari Thales sampai James, Bandung: Remaja Rosdakarya, 1993.

Yusuf, Himyari, Filsafat Di Balik Problematika Kehidupan, Bandar Lampung: Pusikamla, 2009. , Filsafat Imu, Bandar Lampung: Pusikamla, 2009. 
Himyari Yusuf

halaman ini bukan sengaja dikosongkan 